\title{
Synechia vulvae infantum
}

\author{
MUDr. Hana Kosová, Ph.D. \\ Gynekologie Studentský dům, s.r.o., Praha
}

Synechie vulvy je jedním s nejčastějších gynekologických onemocnění dětského věku. Týká se především dětí v tzv. klidovém období, tedy dětí, které mají minimální hladiny ženských pohlavních hormonů. Pokud není zevní genitál správně ošetřován, nejsou mechanicky oddalovány sliznice poševní předsíně, pak nečistoty, zejména smegma, tyto protilehlé sliznice nejprve slepí, vzniklé slepení postupně přeroste epitel a vytváŕí se vlastní srůst, který se nazývá synechie vulvy. Onemocnění se zjistí většinou náhodně při pediatrické prohlídce dítěte, ale někdy může dítěti způsobovat obtiže, děvčátka jsou vyšetřována pro pomočování, pro časté infekce močových cest nebo pro podezření na zánět vulvy a pochvy. Rozrušení synechie se provádí mechanicky ve stadiu konglutinace či tenkého srůstu, silnější srůst je potřeba rozrušit v celkové anestezii. Nejdůležitější je prevence vzniku onemocnění, kterou je správná péče o zevní genitál, jež musí být prováděna nejlépe denně.

Klíčová slova: synechie vulvy, srůst malých stydkých pysků, péče o zevní genitál.

\section{Synechia vulvae infantum}

Synechia vulvae is the most common problem of young children. We can find it in so called rest period, in the time of low levels of women's sexual hormons in blood. If parents don't take care well about external genitalias, dirt and smegma glue together opposite epithelium of vestibuli vaginae and synechia can occure. This illnes doesn't make any problem to affected child, we can find it accidentally during check-up. Problems together with this illness can sometimes occure like enueresis, often urinary tract inflammation or often vulvovaginitis. Opening of vestibuli vaginae we can make in stage of conglutinatio or in stage of thin junction. Thick junctions must be treated by thermocauter in general anesthesia. The most important for prevention of synechia is good care and mechanical dividing opposite parts of epithelium vestibuli vaginae, the best is daily.

Key words: synechia vulvae, conglutination of small labias, care about epithelium vestibuli vaginae.

Synechie vulvy představuje jeden z nejčastějších problémů, který privede malé děvčátko do ambulance dětského gynekologa. Přesto, že je dle Mezinárodní klasifikace nemocí označována jako srůst malých stydkých pysků a je řazena v této klasifikaci v části „vývojové vady genitálu“, vývojová vada to není. Synechie vzniká až po narození dítěte a většinou se nejedná o srůst malých stydkých pysků. S tímto onemocněním se setkáváme převážně v klidovém období, kdy hladina ženských pohlavních hormonů je u dívek minimální. Analogicky se s tímto problémem setkáváme také u starších žen v období po menopauze, kdy je hladina ženských pohlavních hormonů také minimální. Kůže a sliznice zevního genitálu v klidovém období (věk od 6-8 týdnů po porodu až do 8-9 let věku) a především poševní předsíně je velice tenká, tvořená jen několika málo vrstvami vícevrstevného epitelu. Četné mazové žlázky v klidovém období produkují sekret, který společně s odloupanými epiteliemi vytváŕí smegma - bílý, až tvarohovitý bělavý maz (1). Tyto bělavé "drtky“ na zevním genitálu děvčátek nesprávně laici považujíza známku mykotické kolpitidy a ihned na kưži dítěte aplikují volně prodejná antimykotika, která velmi často dítě po aplikaci masti pálí. Není-li smegma rádně odstraňováno slepuje protilehlé sliznice poševní předsíně k sobě a vytváří congulatinatio vulvae. Vzniklou konglutinaci postupně přerůstá tenký epitel, a vytváří se vlastní srůst, který neošetřen může být časem až kožovitě tlustý. $\vee$ tomto prípadě může vzhled genitálu skutečně evokovat diagnózu vrozené vývojové vady genitálu. Dle lokalizace dělíme synechie na dorzální, mediální a ventrální. Ačkoliv se popisuje synechie jako srůst malých stydkých pysků, daleko častěji se setkáváme se srůstem, který začíná v oblasti zadní komisury a postupně uzavírá poševní vestibulum vzhůru k močové trubici (viz obr. 1). V praxi se setkáváme se srůsty, které mnohdy vypadají jako kompletní, na první pohled se zdá, že se jedná o kompletní uzávěr poševní předsíně (která obsahuje ústí uretry a ústí vagíny), ale vždy se při snaze o oddálení stydkých pysků objeví maličký otvor kudy dítě močí. Tento srůst je označován jako synechie dorzální. Méně často se setkáváme se synechií ventrální, tedy faktickým srůstem malých stydkých pysků od klitoris, 
Obr. 1. Synechia vulvae dorsalis

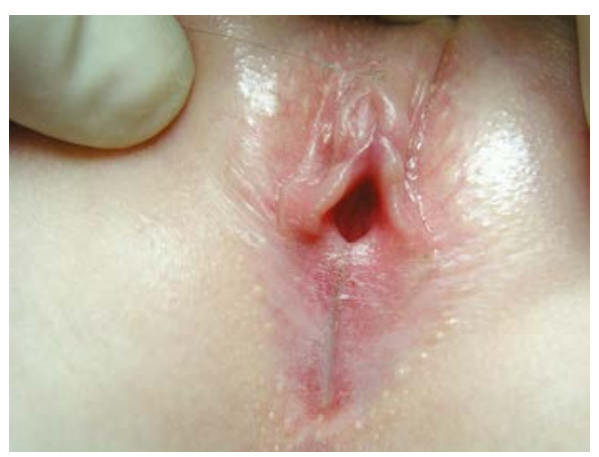

Obr. 2. Synechia vulvae ventralis

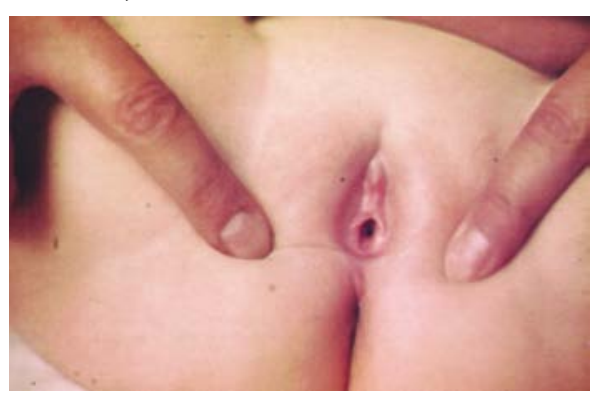

Obr. 3. Synechia vulvae medialis

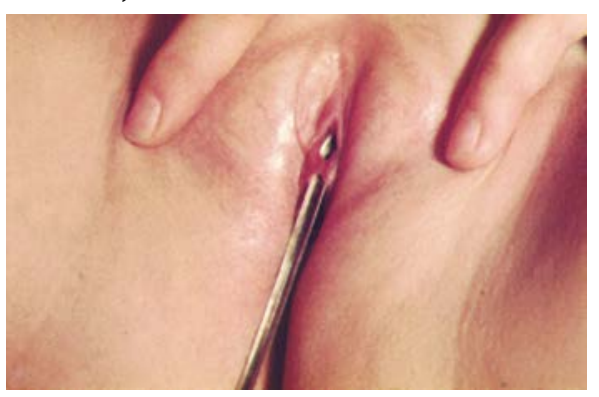

Obr. 4. Fyziologický srůst malého a velkého stydkého pysku označován nesprávně jako synechia lateralis a současně synechia vulvae ventralis incompleta (ačkoliv z obrázku by se zdálo, že se jedná o srưst kompletní, až na malý otvor príizadní komisuře, kudy odtéká moč) a) skutečná synechia vulvae infantum ventralis; b) fyziologický srüst malého a velkého stydkého pysku

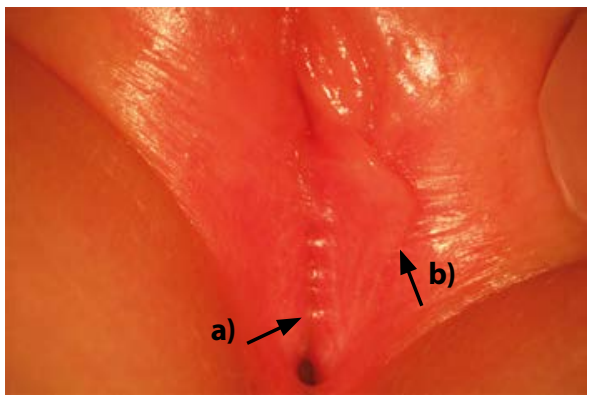

směrem dozadu, ke komisura posterior (viz obr. 2). Velmi vzácně se lze setkat se synechií mediální, tedy srůstem uprostřed poševního vestibula, kdy synechie vytvárí jakýsi můstek mezi močovou trubicí a vstupem do pochvy (viz obrázek 3) (2).

Synechie dítěti může vadit, ale častěji je zjištěna náhodně, při preventivní pediatrické prohlídce, aniž by o tom měli rodiče ponětí, dítě si na nic nestěžuje. Onemocnění se mưže projevovat i tím, že dítě „přečůrává“ nočník, tedy při močení směřuje proud moče dle lokalizace synechie dopředu před nočník (u zadní synechie) nebo dozadu za nočník (při přední synechii). Moč při mikci také zatéká do vzniklé kapsy za srůstem, postupně vytéká a může dráždit zevní genitál, zvláště dojde-li k sekundární bakteriální infekci, dítě si stěžuje na pálení a svědění vulvy, mylně může být toto postupné odtékání moči považováno za známku pomočování. Při chưzi, nebo prudkém dosednutí dítěte se srůst má tendenci spontánně trhat, což děvčátku mưže působit bolest, na kterou dítě upozorní. Při rozsáhlém srůstu může mít děvčátko problém se vymočit. Velmi často jsou odesílány se synechií děti, jež jsou vyšetřovány na urologii pro opakované infekce močových cest, protože stagnující moč za srůstem má tendenci se sekundárně bakteriálně infikovat a rozvijí se zánět.

Se synechií se tedy setkáváme v našich ambulancích velice často. Zdá se, že tohoto onemocnění přibývá (3). Maminky postižených dětí poukazují na to, že byly v porodnici po porodu poučeny, že na genitál novorozeného děvčátka nemají príliš sahat a absolutně netuší, jak se o dívčí genitál správně starat. Pokud matka mechanicky neodstraňuje vznikající smegma, které poměrně pevně ulpívá na sliznici a kưži zevního genitálu a denně mechanicky nerozevírá oblast poševní předsíně, pak je riziko vzniku synechie velice vysoké. Také u pastozních děvčátek je tento problém častější, kdy díky hlubokým kožním záhybům matky tato děvčátka obtížněji ošetřují a synechie vzniká snadněji. Na vině může být také masivní užívání jednorázových plen, kdy vulva dítěte je více ve vlhké zapářce, než u plen látkových, které jsou častěji měněny. Jak již bylo řečeno, nejvíce se s tímto problémem setkáváme u kojenců, batolat a dívek předškolního věku. Ve vyšším věku je již výskyt tohoto onemocnění vzácný, vyskytuje se v tomto období jen u dětí s onemocněním kůže - lichen sclerosus.

Léčba spočivá v tupém rozrušení vzniklého srůstu. Zejména ve stadiu konglutinace či tenkého srůstu je to záležitost několika vteřin. Je potřeba si místo srůstu napnout prsty a následně rozrušit. K rozrušení lez použít sondu, pinzetu, nejjednodušší je využít vlastní prst, kdy masážním pohybem a tlakem ve směru vzniku synechie (u dorzální směrem dozadu ke komi- sura posteriori a u ventrální dopředu ke klitoris) se srůst od začátku až do konce rozruší. Rodiče je potřeba upozornit na to, že několik hodin po rozrušení může dítě díky drobné rané ploše pocitovat pálení při močení, a proto doporučujeme močit ve sprše. Rozrušení srůstu nebolí, jen dítě „„štípne“. Pokud je srůst silnější, je vhodné použít lokální anestezii, nejčastěji používáme Emla 5\% krém, který naneseme na oblast srůstu, necháme pod potravinovou fólií cca 20 min a pak teprve srůst rozrušíme. Následujících 7 dní po rozrušení je vhodné oblast sliznice poševní předsíně ošetřovat epitelizačními mastmi typu HemaGel nebo Infadolan. Při traumatickém, bolestivém rozrušení může mít dítě strach z močení a v praxi jsem se setkala s dětmi, které bylo nutno po traumatickém, násilném rozrušení vycévkovat, proto je doporučena veliká obezřetnost! Silné, kožovité srůsty je potřeba rozrušit v celkové anestezii pomocí termokauteru. $V$ některých zemích je k rozrušení synechií užíváno lokálních mastí s estrogeny nebo kortikoidy. Na rozdíl od úspěchů s ošetření fimózy u chlapců, není aplikace kortikoidních krémů u synechie moc úspěšná Lokální aplikace krémů s estrogeny zase vychází z poznatků, že v období plné estrogenizace se již se synechií nesetkáváme. Sliznice genitálu je díky estrogenu silnější, epitel je mnohovrstevný, řasí se a především nemá tendenci ke slepování. Tyto krémy se však musí užívat dlouho, což vede ke vstřebávání estrogenů kůží a k arteficiálnímu zvýšení hladiny estrogenů v krvi, což může vést k rozvoji sekundárních pohlavních znaků, proto je tato léčba dětskými gynekology zcela zavrhována (4).

Nejdůležitější je však prevence onemocnění! Je nutné rodiče poučit o správné hygieně dívčího genitálu. Vždy radím, denně dưkladně odstranit smegma a krouživým pohybem „masírovat" oblast poševního vchodu a mechanicky tak oddělit protilehlé sliznice. Nejčastěji v ošetřování používáme stejné masti jako při ošetření zadečku - slunečnicový olej, Bepanthen, Sudocrem, atd. Toto je vhodné u malých dětí denně, v pozdějším věku je vhodné jednou či dvakrát týdně dívce zevní rodidla zkontrolovat. Zejména v době, kdy se již dívka chce umývat sama, hrozí, že pokud není dostatečně hlídaná, problém se může objevit velice rychle, z empirie je zřejmé, že srůst se vytváŕí již v během 14 dní.

Poslední dobou se setkáváme s tím, že mnozí horliví lékaři začali rozrušovat i tzv. laterální 
synechii. Jedná se o jednostranný srůst malého a velkého stydkého pysku, který se fyziologicky vyskytuje v klidovém období. Jakjsem již napsala, jedná se o zcela fyziologický srůst, který se samovolně rozruší v době růstu a vývoje zevního genitálu, tedy v období pohlavního dospívání! Synechii, neboli srůst sliznic protilehlých stran poševní předsíně či protilehlých stran malých stydkých pysků, o které hovoříme, pokud mlu-

\section{LITERATURA}

1. Hořejší J. Dětská gynekologie, Avicenum, Praha 1990: 16-226.

2. Altchek A, Deligdisch L. Pediatric, Adolescent and Young víme o synechii vulvae, rozrušujeme proto, že může působit obtí̌e zejména při močení a je zde riziko recidivujících infekcí močových cest díky stagnující moči ve vzniklé kapse za srůstem. Jak již bylo napsáno, často je srůst objeven náhodně při lékařské prohlídce, aniž by dítěti pưsobil jakékoliv obtiže. Naopak „laterální" synechie nepůsobí děvčátku žádné obtíže a z lékařského pohledu se jedná jen o fyziologickou odchylku

Adult Gynecology, Blackwell Publishing LtD, 2009: 12-449. 3. Rome ES. Vulvovaginitis and other common vulvar disorders in children. Endoc. Dev., 2012: 22-72. normy. Přesto se setkáváme s tím, že se někteří lékaři snaží tento srůst násilně rozrušovat. Kromě veliké bolesti, kterou tím dítěti působí, je potřeba si uvědomit, že následné hojení a jizvení může vést k obnovení srůstu, ale také při velikém násili díky jizvám může dojít k deformaci, která bude v pozdějším věku dívce vadit. Jednostranný srůst malých a velkých stydkých pysků tedy za žádných okolností nerozrušujeme.

4. Skřenková J. Každodenní problémy v ambulanci dětského a dorostového gynekologa. Moderní gynekologie a prodnictví, 2015; 23: 241-288. 